\title{
Analysis of Legal Protection for Debtors of Home Loan (KPR) at National Commercial Banks in Indonesia
}

\author{
Deasy Soeikromo* $^{*} \quad$ Michael Barama Sarah D.L Roeroe \\ Lecturer of Faculty of Law, Sam Ratulangi University, Manado, Indonesia
}

\begin{abstract}
Non-performing loan have become a major concern of bank management, including in home loan (KPR), because in addition to causing losses to banks and debtors, they also have an impact on the health and reputation of banks. Initial allegations of causes of KPR problems in addition to the ability of the debtor, fluctuations in income, also the debtor does not know the risk of credit agreements, so the credit agreement is suspected of being legally flawed. This study aims to determine the legal problems in the Credit Agreement, as well as the protection of KPR debtors, in resolving non-performing loans. Research objects of National Commercial Banks in Indonesia, especially banks in North Sulawesi. Conclusion, the legal basis of the Credit Agreement namely The Act No.10 of 1998 concerning Banking that credit is always based on a Credit Agreement between creditors and debtors as a form of binding on both parties, Article 1313 of the Civil Code and Article 1320 of the Civil Code. Legal protection against KPR debtors must be given by reinforcing the rules of the Law/ Government Regulation considering the position of debtors is weak when applying for credit, lack of information and understanding of credit risk at bank KPR.
\end{abstract}

Keywords: home loans, credit agreements, non-performing loan, legal protection

DOI: $10.7176 / J L P G / 82-04$

\section{Introduction}

National banks, both state-owned banks and national private banks operating in Indonesia are financial institutions that play an important role in supporting the national economy, because banks are financial institutions that are places for companies, government and private entities, and individuals to save funds and to be channeled again through the provision of credit facilities including mortgages and various other financial services. The Indonesian economy is currently facing challenges, both from within the country in the form of an increase in consumption and from abroad, namely the turbulence of the world economy which will certainly affect national economic growth.

Based on the 2018 Central Bureau of Statistics (BPS Jakarta 2018a) report, the Indonesian Economy for the first quarter of 2017 compared to the first quarter of 2016 (year on year) grew 5.01\%. For Q4 2016 (q to q) contracted by $0.34 \%$. Indonesia's economic growth, also supported by the growth of financial services, the rate of growth of financial and insurance services in 2014 (4.68), 2015 (8.59) and 2016 (8.90) The field of financial and insurance services grew positively and had significant role for Indonesia's economic growth (BPS Jakarta 2018b).

Economic statistics (BPS Manado 2017) noted that expenditure on household consumption has a positive and significant contribution to the distribution and growth of Manado City GRDP (PDRB), namely in 2014 amounted to $(42,13 \%), 2015(43 \%)$ and $2016(42,15 \%)$. This data shows that the growth of national banking is also supported by the economic capacity of North Sulawesi's growing population. Sularsi, et al. (2016) stated that banks play a very important and crucial role in providing home loan facilities. The high demand for housing makes home loan (KPR) facilities a separate business opportunity which is certainly tempting. Therefore, many banks are competing to provide home loan facilities to the public. Data from BPS Jakarta (2018a) shows that consumer loans have the largest share. One form of consumption credit provided is bank KPR. Through home loan given by BTN, KPR MANDIRI, etc., the community can quickly realize their desire to own a house. It is also seen that the role of BTN in the distribution of mortgages for the people in Indonesia is very dominant. Through BTN the government realizes the development target in housing, specifically to meet the needs of national residents.

Home loan are very beneficial for those who need a home, but it will be dangerous if the home loan is only used for speculation activities by debtors who want to make a profit. Debtors as KPR recipients have long-term obligations to complete the payment of the principal and interest of the loan that has been agreed on in the Credit Agreement. The Act 7 of 1992 concerning Banking which has been amended into The Act No.10 of 1998 requires that the bank in providing credit always bases on the belief that the debtor is able to repay the credit obtained at the agreed time. In other words, the credit provided is guaranteed to return. To obtain this belief, before the bank approves the requested credit, a careful assessment of the debtor's character, ability, capital and business prospects is necessary. Collateral as one of the elements assessed can be in the form of goods, projects, claim rights financed by credit and when it comes to land, agrarian law specifically regulates.

Although home loan have a large contribution to the assets of national banks, however the provision of home loan given a long repayment period, has its own challenges and problems specifically in making the Credit Agreement (PK) and its approval. Home loan that are realized to the right debtor, and understand the PK and home loan credit risk well, will be able to settle their obligations properly. On the other hand, if a home loan that is given 
a defective bank, it will turn into a non-performing loan and eventually must be executed or under the supervision of the bank because the debtor is unable to pay the principal installments and the agreed interest.

The initial survey of the debtors, showing the cause of the home loan problem is that the debtor feels not well informed when making a Credit Agreement (PK) the risk of fines for late payments, the debtor feels he has paid or reduced liabilities but the debt continues to increase or not decrease, feeling unaware of rules for PK, etc. Sularsi et al. (2016) stated that public complaints related to the property industry and banking institutions were included in the top three complaints recorded at the Indonesian Consumers Foundation (YLKI) for the past three years.

The phenomenon of still occurring problems in mortgages in National Commercial Banks, allegedly in addition to the capacity problems of debtors, there are also other problems especially related to legal aspects, such as credit agreements that are made flawed, because the debtor does not understand their rights and obligations properly, when signing the Agreement Credit, there is a pretext that debtors are forced to accept bank requirements because they do not have alternatives (standard contract), etc. This has become a separate problem concerning the legal relationship between home loan debtors and banks in managing credit in national banks, so the main problem is:

- What are the rules of the KPR agreement law at National Commercial Banks in Indonesia?

- What is the legal protection of troubled KPR lenders at National Commercial Banks in Indonesia?

\section{The Bank, Credit and Home loan (KPR)}

The bank is a financial institution whose main activities are receiving deposits, savings and time deposits. The bank is a place to borrow money for people who need it. The bank is not only a "friend of urban society, but also a rural community". Kasmir (2002) stated that the Act No.10 of 1998 concerning Banking, states that the Bank is "Business entity that collects funds from the public in the form of deposits and distributes them to the public in the form of loans and /or other forms in order to improve the lives of many people". The banking law norms that apply in Indonesia, especially those contained in The Act No.10 of 1998 which contain principles, namely the principles of economic democracy, prudential principles, banking principles that support development, banking principles that support stability, the principle of liquidity and professional.

The amount of credit interest is strongly influenced by the amount of deposit interest. The greater or the more expensive the deposit interest, the greater the interest on the loan given, and vice versa. In addition to interest on deposits, the influence of the size of the loan interest is also influenced by the profits taken, operating costs incurred, reserves of risk of bad credit, taxes and other influences (Suyatno 1993). The profit from this interest difference in banks is known as spread based. If a bank experiences a loss from interest difference, where the deposit interest rate is greater than the loan interest rate, then this term is known as a negative spread. For Islamic banks, the term interest is not known in providing services to depositors and borrowers, bank services are adjusted to Islamic law. Sharia principles are financing based on the principle of profit sharing (mudharabah), financing based on the principle of equity participation (musyarakah) the principle of buying and selling goods with profit (murabahah) or capital goods financing based on the principle of pure rent without choice (ijarah) or with the choice of ownership transfer over goods rented from the bank by another party (ijarah wa iqtina).

The establishment of the Financial Services Authority (OJK) is intended to regulate and supervise banks that are independent, accountable, have integrity and are clean of various negative interests and cultures which Bank Indonesia has been exhibiting so far. Through the supervision of the Financial Services Authority, it is expected that the current feudal culture can be lost and a system of banking supervision can be established that can protect the banking industry, the payment system, and guarantee the security of customers (Harahap 2012).

\subsection{Credit agreement}

Agreement (Verbintenis) contains the meaning: "A relationship between the law of wealth / property between two or more people that gives the right of power to one party to obtain achievements and at the same time obliges other parties to perform achievements". Credit agreements between banks and previous debtors must agree on matters that will be determined by the creditor to the customer. So that legal actions or actions carried out by the parties give rise to the Agreement Law relationship, with respect to one party given the right by the other party to obtain an achievement. Whereas other parties provide themselves burdened with an "obligation" to perform achievements. The party entitled to the achievement has a position as a creditor, and the party who is obliged to fulfill the achievement as a debtor.

The Treaty Law only regulates and disputes the relation of objects/wealth which is the object of the agreement between "certain person" (bepaalde persoon). The difference between the law of objects/zakenrecht and the contract law, in the Material Law is "absolute" because:

- Material rights, attached to objects wherever they are. So it has "droit de suite".

- All people are generally bound by an obligation to respect someone's right to the object, "in violable et sacre".

- The owner of the rights to objects, can take any action he likes on the object. 
However, on land relations with someone, it is not emphasized on the rights factor, but emphasizes on the aspects of land use and social functions, so that they are in harmony with the intent and spirit of Article 33 paragraph (3) of the 1945 Constitution (Harsono 1960).

In general, the rights born from the agreement are relative rights, meaning that the right to a new achievement is in a certain person, if it is based on legal relations born of legal actions. Subekti (1986) stated that if the law had established a "subject" agreement, that is, the creditor had the right to achievement and the debtor who was obliged to carry out the achievement, then the essence or "object" of the agreement was the achievement itself. Article 1320 paragraph (4) states: the contents of the agreement must contain the permissible causality (geoorloofde oorzaak). What is the object, or what is the content and achievement goals that give birth to the agreement, must be a legitimate cause (Soimin 1999). In connection with the principle of enforcing the agreement as a law, it relates to formal agreements. One of the reasons why formal agreements must be made in writing and sometimes made by or in the presence of an authorized official, namely:

- The surrender of ownership rights of the transferred material, according to the provisions of Article 613 and Article 616 of the Civil Code, must be carried out in the form of an authentic deed or a deed under the hand. Specifically regarding land rights, the provisions contained in UUPA No.5 of 1960.

- The nature of the contents of the agreement itself, whose material is necessary and must be publicly known. generally this type of agreement can be found in an agreement that aims to establish a legal entity, which in turn will become a standard person in itself.

- Guarantee as an act or legal act that issues a new material law relationship, which has material properties. A contract must meet the legal requirements of the agreement, namely agreement, skills, certain things and a reason that is lawful, as determined by Article 1320 of the Civil Code. By fulfilling the four legal requirements of the agreement, the agreement becomes legal and legally binding for the parties who make it. Regarding the promises made by the developer as stated in the brochure/leaflet circulated as advertisements, according to the classical theory, contract law cannot be held accountable, because these promises are the promises of the contractor who are not listed in the binding of sale and purchase. Beatson and Friedman (1995) stated that according to the classical theory of contract law, home loan consumers cannot claim compensation. However, modern contract theory tends to abolish the formal conditions for legal certainty and emphasizes the fulfillment of a sense of justice. Legal experts generally argue that, the treaty law as regulated in Book III of the Civil Code adheres to the principle of the freedom of contract (Sembiring 2008). Therefore, the parties in making a contract or agreement, are free to determine the desired conditions, provided that they do not conflict with laws, customs and propriety.

\subsection{Credit and Home loan}

Credit is the main source of income and activities to form bank assets, also credit is a risk asset for banks because assets are controlled by outside parties, namely the debtors. The bank wants and strives to ensure that the quality of risk assets is always healthy in a productive and collectable sense (Sutarno 2003). The Act No.10 of 1998 concerning Banking, Article 1 number 11, states that credit is the provision of money or bills that can be equated with it, based on an agreement or agreement between banks and other parties that requires the borrower to pay off the debt after a certain period of time with interest. The contents of the credit agreement regulate the rights and obligations of each party, including the stipulated period and interest, as well as sanctions if the debtor breaks the promise of the agreement. Relations in credit activities between parties are entirely based on mutual trust, namely that the debtor will be able to fulfill everything that has been agreed upon, both regarding the duration, achievements and counter-achievements (Djumhana 2000). The purpose of believing is that the lender believes in the recipient of the credit that the credit disbursed will definitely be returned according to the agreement. Whereas for credit recipients it is the acceptance of trust so that it has an obligation to pay according to the time period (Kansil 2002).

Before credit is given, to convince the bank that the customer is truly trustworthy, the bank first conducts a credit analysis. Credit analysis covers the customer's background, business prospects, guarantees given and other factors. The purpose of this analysis is for the bank to believe that the credit provided is truly safe. Siamat, stated that home loan (KPR) are included in consumer loans, these loans are usually used or used for consumption, either by a person or business entity. Other types of consumer loans such as personal car loans, etc (Siamat 2002). Although preventive safeguards have been carried out but not infrequently, debtors are unable to settle their debts on time in accordance with the agreement and become problem loans. Many causes of problem loans, for example, because the debtor is unable or because of a business downturn and reduced debtor income, etc. The existence of bad credit will be a burden on the bank because in addition to affecting liquidity, also the health and performance of the bank.

\section{Research Method}

This study is a sociolegal study (socio-juridical) with the aim of identifying legal rules for the making of a home loan loan agreement with a National Commercial Bank in Indonesia, identifying the problems that occur in making 
a KPR Agreement and alternative solutions. Legal socio-research is a type of normative legal research. According to Soekamto and Mamudji (2004) normative legal research requires primary, secondary and tertiary legal materials. Primary legal materials are mainly obtained from laws and regulations (Simatupang 2003). The location of this study is in the National Commercial Bank where there are problematic debtors, including: Mandiri Bank, BNI, BRI and BTN spread across North Sulawesi, especially in the cities of Manado, Tomohon, Bitung and Kotamobagu. This research uses primary data from debtors and bank officials. For normative juridical analysis, the focus is on the study of making credit agreements between debtors and creditors and efforts to provide recommendations on legal issues of KPR debtors.

\section{Legal Analysis of Home Loan Agreements at National Commercial Banks in Indonesia}

National banking credit is always based on a credit agreement between creditors and debtors as a form of binding on both parties to the provisions stipulated in the agreed agreement. Article 1313 of the Civil Code regulates agreements as "an act in which one person or more ties himself to one person or more". Simatupang (2003) stated that an agreement can be said to be lawful when fulfilling the conditions as stipulated in Article 1320 of the Civil Code, namely :

- Agree that those who bind themselves: the volunteerism of the parties in binding themselves to an agreement without any element of coercion/compulsion.

- Skills to make an agreement: the parties that bind themselves and agree in an agreement must have been declared a legal subject.

- A certain thing: the object of the agreement must be things that are clear and not vague as a form of guarantee and certainty to the parties that bind themselves in the agreement.

- A reason that is lawful: does not conflict with statutory provisions so that an agreement is prohibited if done or with objects that are against the law.

Bank lending begins with making a credit agreement through both the underhanded deed and notary deed. For those in the form of underhanded deeds, agreements are generally made in the form of a standard agreement in which the bank and the customer sign an agreement that has previously been prepared both the contents and clauses in a printed form. In the case of a notary deed, the bank will ask the notary based on the clauses that have been designed by the bank.

The performance of the agreement in the agreement agreed upon by the parties in the agreement is the implementation of the agreement issued from the agreement. In the event that the debtor does not implement the agreed agreement, the creditor has the right to demand the re-implementation of the agreement which has not, not fully or not at all carried out or which has been carried out in a conflict or not in accordance with the agreement, with or without replacement of interest, losses and costs that has been issued by the creditor. In the Civil Code translated by Subekti and Tjitrosoedibio (1980) it is referred to as with or without burden. Basically the agreement can give birth to a unilateral engagement (where only one party is obliged to achieve) and reciprocal engagement (both parties achieve each other). The definition of a credit agreement contained in The Act No.10 of 1998 concerning Banking, can be taken several elements in terms of credit, namely: 1) An agreement to borrow money, 2) Occurs in the world of banking, 3) For a certain period of time, 4) The interest that has been promised.

If the credit agreement is a special agreement, then there is no agreement named in the Civil Code called the credit agreement. Therefore, what applies is the general provisions of the contract law, plus the clause agreed upon in the contract (Fuady 2005). Although the title of the loan and loan agreement varies, the juridical content of the agreement is essentially the same, namely giving a loan in the form of money. Home loan are part of consumption loans for residential ownership in the form of landed houses or flats or apartments (excluding office houses and shop houses) with collateral in the form of houses provided by banks to individual debtors with the maximum amount of loans determined based on collateral value (Bank Indonesia 2010). Prospective debtors must meet administrative requirements, which are determined by the bank. The applicant completes and submits all the requirements specified by the bank, for further verification of eligibility based on the applicant's data, if the applicant is deemed feasible and fulfills the requirements then the next step is the signing of the Credit Agreement, then the credit is realized, in the form of credit cash to the debtor/book-entry to the account designated by the debtor, namely the account of the developer/developer who sells the house to the debtor.

When signing the Credit Agreement, according to the agreement reached between the debtor and the bank, and stated in the Credit Agreement, then each party will obtain their rights and obligations. What is the right of the debtor is an obligation on the part of the bank and what is the obligation of the debtor is the right of the bank.

In the case of a credit agreement it is also determined that in order to guarantee the repayment of the credit received, the debtor must submit collateral goods along with proof of ownership of the original collateral at the bank to be bound in accordance with the provisions of the law, in this case the binding with the Underwriting Right. All costs required for binding collateral items are the obligation of the debtor. In addition, the debtor is also obliged to cover collateral insurance for the value and type of risk of fire and its expansion (landslides, earthquakes, floods) during the credit period or all debts have not been repaid by the debtor. Another important thing in the 
credit agreement is the choice of law. In the agreement, it was determined that regarding the implementation and interpretation of the agreement, the Civil Law as stated in the Civil Code and the regulations in force in Indonesia.

Data from the Infobank Research Bureau, as of February 2016 the total credit disbursed by commercial banks reached IDR 3,967.91 trillion. The number increased by $8.24 \%$ compared to the same period last year which amounted to Rp3,665.69 trillion. The share of credit for property is quite large, from special banks such as BTN, which account for more than 80 percent of total loans, reaching Bank Muamalat, BII where the proportion is almost half of all loans channeled, or Panin Bank, Permata Bank etc. ranging from a dozen to 20 percent (Infobanknews.com 2016).

Whereas specifically for KPR channeled by large commercial banks in Indonesia, the amount varies, ranging from under 10 trillion such as Danamon Bank, Permata Bank etc., to tens of trillions such as Mandiri Bank, BNI, $\mathrm{BCA}$ and so on, the highest number is still led by BTN which is special housing bank in Indonesia. At the National Commercial Bank, the process of buying a home by way of a home loan includes:

- Preliminary agreement between the consumer and the developer company, in which the agreement has been agreed on the first payment as a down payment, the location and type of house purchased, the price of land $\&$ buildings, the period of construction of the house and the time of delivery of the house;

- Submission of Application for Home loan by Developers for and on behalf of consumers at Bank KPR providers. The loan period is between 5 and 15 years, which will be adjusted to the ability of consumers to pay the installments.

In the implementation, the process of ownership of houses through KPR, will bring up various problems that must immediately get a solution. One of the problems, for example, is the guarantee of credit that will be received by the bank and its binding procedures. Credit guarantees on mortgages are houses to be purchased by customers, the problem that arises is that when the credit has been approved and realized, the bank has previously spent money to pay the house to the developer, where ownership rights to land and buildings have not been transferred to credit recipients, so that the bank must wait for the process of renaming and carry out the process of binding credit guarantees to the land and buildings. Another problem is the potential default of the debtor, arguing that they did not pay installments because the quality of the house received was not in accordance with the specifications offered by the developer in the previous brochure/explanation.

\section{Legal Protection Against Home Loan (KPR) Debtors at National Commercial Banks}

The Act No.10 of 1998 provides guidance so that banks in carrying out lending activities are always based on the belief that the debtor is able to repay the credit obtained at the agreed time. It is confirmed that the guarantee in granting credit is a belief in the ability and ability of the debtor to repay its obligations in accordance with the agreement.

To avoid non-performing loans, the Bank has actually carried out preventive security by carrying out in-depth analysis of the business and income as well as the ability of the debtor. Analysis of legal aspects has also been carried out such as the legality of the debtor, the legality of the debtor's business, the authority of the person acting on behalf of the company, the legal validity of the collateral, borgtocht and continuous monitoring and supervision. Even though preventive safeguards have been carried out but not infrequently, debtors are unable to settle debts on time in accordance with the credit agreement so that they become problem loans. Many causes of problem loans, for example, because the debtor is incapable or because of a business downturn and the failure of the business which results in reduced debtor business income or indeed the debtor intentionally does not want to pay because the character of the debtor is not good.

Factors causing defaults in the KPR Credit Agreement at National Commercial Banks can be categorized into two groups, namely:

- Default that occurs as a result of negligence from the debtor;

- Defaults that occur due to weak credit supervision from the bank.

Defaults that occur as a result of negligence from the debtor in the form of arrears in the payment of credit installments from the debtor and this is the cause of the most defaults on mortgages in the National Commercial Bank. However, based on information from several research informants who had been in arrears in paying installments, they were in arrears in installments due to financial difficulties caused by sudden family needs such as sick family members, and large costs or their termination of work main because of economic changes. In addition, there are indeed some customers who deliberately do not pay credit installments for several months because they feel they have never been reprimanded or warned by the bank because of delinquency. Other reasons the terms given by the bank are too heavy after the credit is disbursed, where this is not given a prior explanation by the bank.

This shows that supervision of the implementation of mortgages by the bank is still weak because customers who do not pay installments should immediately be warned of delays and sanctions that will be received by the debtor. Other problems are: 1) when the home loan will be taken by the debtor, there are limited consumers in choosing KPR products, 2) the understanding of debtors is weak because of the lack of information from business 
actors.

The research informant stated that the limited alternative for them to choose the product offered by the developer/bank home loan provider, reflects the position of the debtor who is weak and without choice, this position will adversely affect the health of bank credit. The lack of information possessed by debtors is the cause of problems in home loan, which causes informants not to understand the risks to be faced. This has an impact on the low awareness of the home loan product that has been agreed upon, the inability of the debtor to fight for his rights, and the quality of the building occupied by the debtor which is deemed not to be as expected.

Likewise the lack of understanding of research informants on the Credit Agreement that has been made/ signed. They do not understand well, as a result of the payment of the agreed installments. Whereas in the previous agreement it was agreed that if the debtor defaulted, especially in the case of inability and the late installment payment, it would be fined according to the agreement. This sanction results in the imposition of penalties for late payment of principal and interest on loans, until the execution of collateral for the debtor.

Some informants also did not know at all that the house certificate they were occupying had been given home loan rights to secure bank credit, because they had never been informed in advance. Installation of Underwriting Rights, by the bank because the bank will later have the right to obtain payment from the guarantee, if it turns out that the debtor breaks the promise, because it does not pay off the principal debt and credit interest that has been agreed upon through a credit agreement. As a result of the debtor's default, the bank can make a legal suit to the District Court, so that it is expected that through the claim the loss experienced by the creditor can be reimbursed through the sale/ confiscation of the Underwriting Right object. In practice it is not uncommon for banks as lenders to experience difficulties, especially when billing debtors, due to delinquent payments of principal and interest on the debtor's credit to the bank. Unpaid debtors' interest and loan principal will cause the bank to experience difficulties, especially in fulfilling its obligations to third parties. Usually if the credit rescue done by the bank is unsuccessful, then the last step is to seek credit payments and interest arrears through the sale of collateral objects that have been installed with the right of ownership with the object of the debtor's home loan rights.

\section{Conclusion}

Credit Agreement on KPR National Commercial Banks in Indonesia, the legal rules are based on The Act No.10 of 1998 concerning Banking which stipulates that credit in general and banking credit in particular is always based on a credit agreement between creditors and debtors as a form of binding on both parties to the provisions stipulated in the agreed agreement. The implementation of the achievements in the credit agreement agreed upon by the parties is the implementation of the agreement issued from the agreement. If the debtor does not implement the agreed agreement, the creditor has the right to demand the re-implementation of the agreement that has not, not fully or not at all carried out or that has been carried out in a conflict or not in accordance with the agreement, with or without replacement of interest has been issued by the creditor.

Legal protection must be given to troubled home loan debtors, especially to: a) weak debtor position due to limited alternatives to product selection, this position will have a negative impact, either for the debtor or the bank providing home loan loans as creditors; b) Weak Debtor Understanding because of the lack of information from the Business Actor/the Bank, the lack of information causes the debtor to not understand the risks that will later be faced; c) The contents of the Credit and Information Agreement that are not balanced between the debtor and the bank; d) Debtors do not understand well, the adverse effects of the payment of the principal installments and the agreed credit interest; e) The debtor does not understand why the house must be executed by the bank and feels not well informed beforehand, the consequences and consequences of the installments in arrears.

\section{Acknowledgments}

The authors would like to thank the management and employees of Mandiri Bank, BNI, BRI and BTN in North Sulawesi, especially in the cities of Manado, Tomohon, Bitung and Kotamobagu, as well as informants who participated in this study. The funding of this study comes from the Higher Education Leading Basic Research Scheme (PDUPT), Year 1/2018 which is provided by the Directorate General of Research and DevelopmentKemenristek Dikti, Indonesia.

\section{References}

Central Bureau of Statistics-BPS, Jakarta. (2018a). Monthly Report on Socio-Economic Data, Issue 84 May 2017. Catalog 9199017. Accessed on 16 July 2018.

-BPS Jakarta. (2018b). Growth Rate and Distribution of GDP According to Business Fields for 2014-2016. Retrieved July 16, 2018 , BPS Manado. (2017). GRDP Distribution of Current Prices in Manado City according to Expenditures for 2010-2016. Retrieved July 16, 2018.

Bank Indonesia. (2010) Guidelines for Preparation of the Standard Operating Procedure for Home Loan Administration for Securitization. Jakarta: Bank Indonesia. https://www.bi.go.id/.../ 
perbankan/.../768335eb0f2146d9ad5279c4ec055a7blampiran... Accessed on 16 July 2018.

Beatson, J. and Friedman, D. ed. (1995). Good Faith and Faults in Contract Law. Oxford: Clarendon Press.

Djumhana, M. (2000). Banking Law in Indonesia. Bandung: PT. Citra Aditya Bakti.

Fuady, M. (2005). Introduction to Business Law. Organizing Modern Business in the Global Era. Bandung: PT. Citra Aditya Bakti.

Harahap Y.M. (2012). Legal Aspects of the Agreement, Bandung: Alumni.

Harsono B. (1960). Indonesian Agrarian Law Association of Land Law Regulations. Jakarta: Djambatan.

Infobanknews,com. (2016). Bank Credit Growth Reaches 8.24\%. Jakarta: Infobank. http://infobanknews.com/. accessed 5 February 2019.

Kansil, C.S.T. (2002). Principles of Knowledge of Indonesian Commercial Law. Jakarta: Sinar Grafika.

Kasmir. (2002). Banks and Other Financial Institutions. Sixth Edition, Jakarta: PT. RajaGrafindo Persada.

Sembiring, S. (2008). Commercial Law. Bandung: PT. Citra Aditya Bakti.

Siamat, D. (2002) Management of Commercial Banks. Jakarta: Intermedia.

Simatupang, W.L. (2003). "Legal Protection Against Debtors BTN KPR Agreement Viewed from The Act No.8 of 1999 concerning Consumer Protection”, Jakarta: University of Indonesia, Law Faculty. Thesis. 22-23.

Soekamto S, and Mamuji, S. (2004). Normative Legal Research A Brief Review, Jakarta: PT. Raja Grafindo Persada.

Soimin, S. (1999). Civil Code, Jakarta: Sinar Grafika.

Subekti R. (1986). Agreement Law. Jakarta: Intermasa.

Sularsi, Bintoro, M.A. \& Baasith, A. (2016). "Banking Policies and Practices in Indonesia: KPR Distribution Study, Regarding the Principle of Consumer Protection”. Jakarta: Indonesian Consumers Foundation (YLKI) and Perkumpulan Prakarsa.

Sutarno. (2003). Legal Aspects of Credit at Banks. Bandung: Alfabeta.

Suyatno, T. (1993). “Banking Institution”. Jakarta: PT. Gramedia.

The Act 7 of 1992, concerning Banking which has been amended into The Act No.10 of 1998 . 